\title{
Diagnosis of Pulse Production and Consumption in Uttar Pradesh: An Inter Regional Analysis
}

\author{
Rooba Hasan ${ }^{1 *}$ and D.N. Khan ${ }^{2}$ \\ ${ }^{1}$ Department of Agricultural Economics, Institute of Agricultural Sciences, BHU, Varanasi- \\ 221005, India \\ ${ }^{2}$ SBI Commercial Branch, Near GPO Square, Indore-452001, India \\ *Corresponding author
}

\section{A B S T R A C T}

\begin{tabular}{|l|}
\hline K e y w o r d s \\
Production, \\
Consumption, \\
Pulses, Growth, \\
Uttar Pradesh \\
\hline Article Info \\
\hline $\begin{array}{l}\text { Accepted: } \\
\text { 08 June } 2018 \\
\text { Available Online: } \\
\text { 10 July 2018 }\end{array}$ \\
\hline
\end{tabular}

India is the largest producer and consumer of pulses in the world. However the production and consumption of pulses in India is low with inter-regional variations and the growth rate of area and production of pulses is negligible as compared to cereals. Many studies have been done for the different state of the country but no study has been done inter regionally for the state of Uttar Pradesh. This study has analyzed the production pattern and consumption pattern of pulses in different regions of Uttar Pradesh. The study is based on secondary data collected from published sources. Compound growth rate was estimated to study the yield performance of pulses in different regions of the state. Consumption pattern among rural and urban households and across different regions was analyzed. It was observed that production of pulses in Uttar Pradesh has decreased from 49 lakh tones (1995) to 27 lakh tones (2009) and yield has decreased from 17q/ha (1995) to 10 $\mathrm{q} / \mathrm{ha}(2009)$ respectively. Bundelkhand region was found as dominant in pulse production with about 11 lakh hectares of area and 16.86 lakh tones production in triennium ending (TE) 2009, growth rate was also highest in Bundelkhand region in 2000-09. The share of pulses in consumption basket was not uniform among the regions and showed interregional variations.

\section{Introduction}

Pulses are the important sources of proteins, with high fiber content and low glycemic index. Pulses occupy predominant position in discussions related to food and nutritional security, particularly for low income consumers as it is popularly known as "poor man's meat and 'rich man's vegetable. In India due to diverse agro climatic conditions pulses are grown throughout the year. India is the largest producer and consumer of pulses accounting for about 26 per cent of global production, 28 per cent of their global consumption and 35 per cent of global area under pulses (FAO STAT). Realizing the importance of Pulses for human diet, 2016 was declared as international year of pulses. However, the growth in production and yield of pulses has lagged behind the growth rate of country's population and this resulted a decline in per capita availability of pulses 
from $66 \mathrm{gm} /$ day during triennium ending 1965 to $33 \mathrm{gm} /$ day during triennium ending 2005 (Agricultural Statistics at a Glance, 2007). Expert Committee on Pulses, 2012 observed that the differential impact of technologies, high yielding varieties and irrigation has substantially affected area under pulses. Cereal production (mainly rice and wheat) has increased but a decline in the percentage share of coarse grains and pulses was observed in total food grains production since 1960s (Goyal and Singh, 2002). Shrivastava et al., (2005) observed that the production of pulses decreased by 3.6 per cent and the per capita daily availability of pulses decreased by 36.64 per cent. Examination of past studies showed that there is gradual decline in production and consumption of pulses. Most of the studies have been done on national level and dividing the nation into different regions. Many studies have been done for the different state of the country. However, no study has been done particularly for the state of Uttar Pradesh. Thus, present study was conducted to examine production pattern, growth rate and consumption pattern of pulses in different regions of Uttar Pradesh.

\section{Materials and Methods}

The present study incorporates the production pattern, growth and consumption of pulses for the state Uttar Pradesh. The state was divided into 4 economic regions viz., Eastern, Western, Central Plain and Bundelkhand, list of districts in each region is given in appendix1. These regions exhibit wide variations in agro-climatic conditions, resources endowment and food consumption habits. The production and consumption pattern of pulses was studied for these regions. The study was primarily based on secondary data collected from various published sources like Sankhiyiki Patrika of Uttar Pradesh, Uttar Pradesh Bulletin of Agriculture Statistics, Government of India etc. The spatial and temporal production pattern of pulses was investigated by using simple tabular analysis. Further, Compound growth rates (CGR) of area, production and yield of pulses were estimated as follows:

$$
\begin{aligned}
& \mathrm{Y}_{\mathrm{t}}=\mathrm{AB}^{\mathrm{t}} \\
& \text { Where, } \\
& \mathrm{Y}_{\mathrm{t}}=\text { area/production/yield of major } \\
& \text { crops in } \mathrm{t}^{\text {th }} \text { period, } \\
& \mathrm{t}=\text { time variable }(1,2,3 \ldots \ldots, \mathrm{n}) \text {, } \\
& \mathrm{A}=\text { constant, } \\
& \mathrm{B}=(1+\mathrm{r}) \\
& \mathrm{r}=\quad \text { compound growth rate. }
\end{aligned}
$$

After $\log$ transformation and estimation of the above function as $\ln \mathrm{Y}_{\mathrm{t}}=\ln \mathrm{A}+\mathrm{t} \ln \mathrm{B}$, compound growth rate was estimated as:

$$
\mathrm{r} \quad=\quad\{\operatorname{antilog}(\ln \mathrm{B})-1\} * 100
$$

To understand the extent of instability in the yield of agricultural commodities, the coefficient of variation (CV) was estimated as follows:

$$
C V=\frac{\sigma_{x}}{\bar{X}} * 100
$$

Where,

$\begin{array}{rll}\frac{\sigma_{\mathrm{x}}}{X} & = & \text { standard deviation of } \mathrm{X}, \\ \mathrm{X} & = & \text { mean of } \mathrm{X} . \\ & = & \text { area/production/yield }\end{array}$

The consumption pattern of pulses was analyzed spatially and across rural and urban sectors using household level consumption data from consumption expenditure survey conducted by National Sample Survey Organization (NSSO). To study the consumption pattern data was taken from rounds number 66 pertaining to the period 2009-10. Unit level data regarding consumption of food commodities during last 30 days was extracted and used for the analysis. For studying spatial consumption 
pattern, Uttar Pradesh was divided into four geographical regions viz., Eastern, Western, Central and Bundelkhand regions. The estimated values of monthly per capita consumption expenditure (MPCE), which was taken as a proxy of income, for each sector as well as Uttar Pradesh, the terms consumption expenditure (MPCE) and income were used synonymously hereafter. Broadly, to study consumption pattern of agricultural commodities, per capita consumption and budget shares of food groups were estimated as follows:

Per capita consumption and budget share

Monthly per capita consumption (consumption expenditure) for food groups was estimated using following formula:

$$
M P C=\frac{\sum_{i=1}^{n} C_{i}}{\sum_{i=1}^{n} f_{i}}
$$

Where,

MPC $=$ monthly per capita consumption (kg)/expenditure (Rs),

$\mathrm{C}_{\mathrm{i}}=$ monthly

consumption/expenditure on food item by $i^{\text {th }}$ household,

$\mathrm{n}=$ number of sample household, and

$f_{i}=$ family size of $i^{\text {th }}$ sample household.

The share of food groups in total consumption expenditure was measured using following formula:

$$
W_{g}^{t}=\frac{M P C_{E_{g}}^{t}}{\sum_{g=1}^{m} M P C_{E_{g}}^{t}} \times 100
$$

Where,

$W_{s}^{t}=$ share of $\mathrm{g}^{\text {th }}$ food group in total food consumption expenditure in $\mathrm{t}^{\text {th }}$ period,

$$
M P C_{E g}^{t}=\text { monthly per capita }
$$

consumption expenditure on $\mathrm{g}^{\text {th }}$ food group in $\mathrm{t}^{\text {th }}$ period, and

$\mathrm{g}=$ number of food groups $(\mathrm{g}=1$, 2 ...m) in food basket.

Consumption and budget shares were estimated across different regions and among rural and urban sectors to assess the spatial changes in consumption pattern. Per cent change in per capita consumption; budget share over the period under consideration were finally tabulated to interpret results.

\section{Results and Discussion}

\section{Spatial and temporal production pattern of pulses}

Pulses are an important component of any discussion related to food and nutritional security and environmental sustainability. Besides their nutritional value (about 20-30 per cent protein), pulses enhance productivity of soil in terms of nitrogen, thereby positively impacting the yield of subsequent crops.

In Uttar Pradesh, pulses are largely cultivated in Bundelkhand region. Pulses occupied about 11 lakh hectare of area with production of 16.86 lakh tones in TE 2009 in Bundelkhand region (Table 1). The Eastern region was found to be second largest contributor to total pulses area with 6.02 lakh ha area. On the other hand, Western region had only 2.09 lakh ha area under pulses.

Growth in area under pulses was highest in Bundelkhand region (5.02 per cent) followed by Eastern region ( 0.41 per cent) and Central Plain region (1.43 percent), conversely growth was insignificant in Western region (-2.48 per cent) during 1991-00. The period between 1991 and 2000 witnessed a drastic reduction in growth rate in production and yield of pulses. Further, during 2000-09 growth rate in area of pulses was insignificant in all the 
regions and Uttar Pradesh. Although a remarkable increase in growth rate in production and yield of pulses was observed in Bundelkhand region (9.94 per cent) and yield (11.65 per cent) during 2000-09, during this period growth rate in production was insignificant in Central plain and Bundelkhand region while Western (1.53 per cent) and Eastern regions (1.09 per cent) showed a considerable growth rate in yield as compared to period 1991-00 (Table 2).
Region and sector wise share of pulses in total food expenditure in Uttar Pradesh

It was pertinent to study the consumption pattern across the regions because consumption habit of the people varies. Thus, consumption pattern pulses were studied both spatially and among rural and urban households for 2009. The share of food in total consumption expenditure was found to be about 52 per cent and 42 per cent in rural and urban sectors, respectively (Table 3).

Table.1 Region wise area, production and yield of pulses in Uttar Pradesh

\begin{tabular}{|c|c|c|c|c|c|c|c|c|c|c|c|c|}
\hline \multirow[t]{2}{*}{ Region } & \multicolumn{4}{|c|}{$\begin{array}{c}\text { Area } \\
\text { (lakh ha) }\end{array}$} & \multicolumn{4}{|c|}{$\begin{array}{l}\text { Production } \\
\text { (lakh tones) }\end{array}$} & \multicolumn{4}{|c|}{$\begin{array}{l}\text { Yield } \\
\text { (q/ha) }\end{array}$} \\
\hline & 1995 & 2000 & 2005 & 2009 & 1995 & 2000 & 2005 & 2009 & 1995 & 2000 & 2005 & 2009 \\
\hline Eastern & 8.49 & 7.36 & 6.38 & 6.02 & 14.57 & 6.40 & 5.20 & 5.40 & 17.25 & 8.70 & 8.13 & 9.02 \\
\hline Western & 3.82 & 3.24 & 2.61 & 2.09 & 4.79 & 2.20 & 2.09 & 1.73 & 12.53 & 6.88 & 8.02 & 8.32 \\
\hline Central Plain & 4.93 & 4.64 & 4.24 & 3.79 & 8.48 & 6.12 & 3.49 & 2.86 & 17.30 & 13.15 & 8.25 & 7.58 \\
\hline Bundelkhand & 8.68 & 11.22 & 13.35 & 10.89 & 21.08 & 9.61 & 11.56 & 16.86 & 23.94 & 8.58 & 8.63 & 15.38 \\
\hline U.P. & 25.93 & 26.46 & 26.58 & 22.79 & 48.92 & 24.34 & 22.34 & 26.85 & 17.75 & 9.32 & 8.26 & 10.08 \\
\hline
\end{tabular}

Table.2 Region wise compound growth rate of area, production and yield of pulses in Uttar Pradesh

(in per cent)

\begin{tabular}{|c|c|c|c|c|c|c|c|c|c|}
\hline \multirow[t]{2}{*}{ Region } & \multicolumn{2}{|c|}{ Area } & \multicolumn{2}{|c|}{ Production } & \multicolumn{2}{|c|}{ Yield } & Area & Production & Yield \\
\hline & $\begin{array}{c}1991- \\
00\end{array}$ & $\begin{array}{c}2000- \\
09\end{array}$ & $\begin{array}{c}1991- \\
00\end{array}$ & $\begin{array}{c}2000- \\
09\end{array}$ & $\begin{array}{c}1991- \\
00\end{array}$ & $\begin{array}{c}2000- \\
09\end{array}$ & & 1991-2009 & \\
\hline Eastern & 0.41 & -1.72 & -10.94 & -0.65 & -11.30 & 1.09 & $\begin{array}{c}-2.10 \\
(16.60)\end{array}$ & $\begin{array}{c}-6.41 \\
(45.76)\end{array}$ & $\begin{array}{c}-4.39 \\
(36.28)\end{array}$ \\
\hline Western & -2.48 & -4.24 & -14.17 & -2.77 & -11.98 & 1.53 & $\begin{array}{c}-4.13 \\
(22.95)\end{array}$ & $\begin{array}{c}-6.63 \\
(52.02)\end{array}$ & $\begin{array}{c}-2.61 \\
(34.76)\end{array}$ \\
\hline Central Plain & 1.43 & -2.29 & -6.62 & -4.21 & -7.94 & -1.97 & $\begin{array}{c}-1.32 \\
(13.75)\end{array}$ & $\begin{array}{c}-7.33 \\
(44.40)\end{array}$ & $\begin{array}{c}-6.09 \\
(41.99)\end{array}$ \\
\hline Bundelkhand & 5.02 & -1.54 & -11.44 & 9.94 & -15.67 & 11.65 & $\begin{array}{c}2.47 \\
(17.14)\end{array}$ & $\begin{array}{c}-0.07 \\
(53.74)\end{array}$ & $\begin{array}{c}-2.48 \\
(66.54)\end{array}$ \\
\hline U.P. & 1.93 & -1.97 & -10.82 & 1.56 & -11.80 & 3.53 & $\begin{array}{l}-0.34 \\
(7.92)\end{array}$ & $\begin{array}{c}-3.84 \\
(41.52)\end{array}$ & $\begin{array}{c}-3.98 \\
(41.98)\end{array}$ \\
\hline
\end{tabular}

Figures within parentheses are coefficients of variation (CV) 
Table.3 Region and sector wise share of food commodities in total food expenditure in Uttar Pradesh in 2009-10

\begin{tabular}{|l|l|l|}
\hline \multicolumn{1}{|c|}{ Region } & Pulses & Food* \\
\hline RURAL & & \\
\hline Eastern & 9.06 & 13.34 \\
\hline Western & 7.14 & 52.53 \\
\hline Central plain & 9.18 & 54.91 \\
\hline Bundelkhand & 6.74 & 45.99 \\
\hline Total & 8.34 & 52.82 \\
\hline URBAN & & \\
\hline Eastern & 8.40 & 48.69 \\
\hline Western & 6.66 & 42.31 \\
\hline Central plain & 8.40 & 40.91 \\
\hline Bundelkhand & 6.20 & 36.95 \\
\hline Total & 7.40 & 42.65 \\
\hline TOTAL & & \\
\hline Eastern & 8.97 & 52.22 \\
\hline Western & 6.97 & 48.54 \\
\hline Central plain & 8.97 & 50.23 \\
\hline Bundelkhand & 6.60 & 43.25 \\
\hline Total & 8.10 & 49.84 \\
\hline
\end{tabular}

(per cent)

Appendix.1 List of districts in each region

\begin{tabular}{|c|c|c|c|}
\hline \multicolumn{4}{|c|}{ REGIONS } \\
\hline Eastern & Western & Central Plain & Bundelkhand \\
\hline $\begin{array}{l}\text { Fatehpur, Pratapgarh, } \\
\text { Allahabad, Kausambi, } \\
\text { Maharajganj, } \\
\text { Gorakhpur, Devaria, } \\
\text { Kushinagar, Jaunpur, } \\
\text { Gazipur, Varanasi, } \\
\text { Chandauli, Mau, } \\
\text { Azamgarh, Balia, } \\
\text { Sidhharth Nagar, } \\
\text { Basti, Sant Kabir } \\
\text { Nagar, Mirzapur, } \\
\text { Sonbhadra, Bhadoi, } \\
\text { Behraich, Gonda, } \\
\text { Shravasti, Balrampur }\end{array}$ & $\begin{array}{l}\text { Aligarh, Mathura, } \\
\text { Agra, Firozabad, } \\
\text { Mainpuri, Badaun, } \\
\text { Mahamaya Nagar, } \\
\text { Bareilly, Pilibhit, } \\
\text { Shahjahnpur, Meerut, } \\
\text { Ghaziabad, Bijnor, } \\
\text { Baghpat, } \\
\text { Bulandshahar, } \\
\text { GautumBudh Nagar, } \\
\text { Eta, Moradabad, } \\
\text { Rampur, } \\
\text { Jyotibaphulenagar, } \\
\text { Saharanpur, Muzaffar } \\
\text { Nagar }\end{array}$ & $\begin{array}{l}\text { Farukkhabad, Etawah, } \\
\text { Kanpur Dehat, } \\
\text { Kanpur Nagar, } \\
\text { Kannuj, Orrya, } \\
\text { Lakhimpur Kheri, } \\
\text { Sitapur, Hardoi, } \\
\text { Unnao, Lucknow, } \\
\text { Raibareily, Barabanki, } \\
\text { Faizabad, Sultanpur, } \\
\text { Ambedker Nagar }\end{array}$ & $\begin{array}{l}\text { Jalaun, Ambedkar } \\
\text { Nagar, Jhansi, } \\
\text { Lalitpur, Hamirpur, } \\
\text { Banda, Mahoba, } \\
\text { Chitrakoot }\end{array}$ \\
\hline
\end{tabular}


The share of pulses was higher in rural sector as compared to urban sector. Higher consumption of pulses in rural sector may be because of high calorie requirement, easy availability of pulses and payment of wages in kind form in rural sector. Among the regions, highest share in consumption of pulses was observed in Central Plain region (9.18 per cent) in rural sector and Eastern and Central Plain region (8.40 per cent) in urban sector.

The pulse consumption was found to be more biased towards non-traditional regions as compared to traditional pulse producing region (Bundelkhand region) in rural sector but in urban sector it was biased towards second pulse producing region (Eastern Region). In Uttar Pradesh consumption of pulses was highest in eastern and central plane region (8.97 per cent). Thus, it can be generalized that the share of pulses in food was not uniform among the regions and showed inter-regional variations. The interregional variations may be due to some differences in tastes and preferences of consumers across the regions because of large cultural diversity and consequent differences in food histories across different regions of the state.

\section{References}

Bardhan, D., Tewari, S. K. and Dabas, Y. P. S. (2008), "Trends in consumption of food commodities: a global perspective. (Special Issue: Food management in India in global perspective.)", Agricultural Situation in India, 65: 5, 309-316. 4.
Consumer Expenditure Survey, $43^{\text {rd }}$ and $66^{\text {th }}$ round, NSSO, Ministry of Statistics and Programme Implementation, GOI, New Delhi.

Fahimuddin (2010), "Diversification of agriculture in Uttar Pradesh: need for policy reorientation", Journal of Rural Development (Hyderabad), 29: 2, 141156.

Gajbhiye, Sonal, Wankhade, R. N. and Kakde, S. J. (2010), "Growth and instability of chickpea production in Vidarbha region of Maharashtra", International Journal of Commerce and Business Management; 3: 2, 172174.

Goyal, S. K and Singh, J. P. (2002), "Demand Versus Supply of Foodgrains in India: Implications to Food Security", Paper prepared for presentation at the 13th International Farm Management Congress, Wageningen, The Netherlands, July 7-12.

Hasan, Rooba, Srivastava and Mathur (2012) Spatial and temporal Consumption and production pattern of pulses in India. Journal of Interacademicia, 16(2):375-384

Shrivastava, K. K., Saxena, P. and Sahai, V. (2005), "Food security in India: status and strategy Analysis", Indian journal of Agricultural Economics, pp.426.

Srivastava S.K, Shivramane and Mathur, V.C. (2010)"Diagnosis of pulse performance of India", Agricultural Economics Research Review, 23(1):137-148.

\section{How to cite this article:}

Rooba Hasan and Khan, D.N. 2018. Diagnosis of Pulse Production and Consumption in Uttar Pradesh: An Inter Regional Analysis. Int.J.Curr.Microbiol.App.Sci. 7(07): 860-865. doi: https://doi.org/10.20546/ijcmas.2018.707.105 